\title{
ANALISA PENGARUH PEMBEBANAN TERHADAP EFISIENSI GENERATOR DI PLTG BORANG DENGAN MENGGUNAKAN SOFTWARE MATLAB
}

\author{
Muhammad Noer \\ Dosen Politeknik Negeri Sriwijaya pada Program Studi Teknik Elektro \\ e-mail : mnjphiliang@gmail.com
}

\begin{abstract}
ABSTRAK
Untuk mengetahui nilai efisiensi generator dan rugi daya pada PLTG Borang, dilakukan perhitungan secara manual serta menggunakan software MATLAB, Perhitungan efisiensi generator dan rugi daya dengan menggunakan software MATLAB dilakukan dengan mengumpulkan data-data berupa daya dan arus beban terpakai generator. Berdasarkan hasil perhitungan manual dan dengan menggunakan software MATLAB berbasis GUI, efisiensi tertinggi pada PLTG Borang didapat saat beban puncak sebesar $99,88 \%$. Sedangkan efisiensi terendah untuk hasil perhitungan manual didapat saat beban tertinggi sebesar 99,87 \% . Dan hasil perhitungan rugi daya dengan perhitungan manual lebih kecil jika dibandingkan dengan menggunakan software MATLAB, rugi daya terkecil pada saat beban puncak adalah 0,0112 MW dan rugi daya terbesar pada saat beban puncak adalah 0,0136 MW. Efisiensi dan Rugi daya sangat dipengaruhi oleh daya dan arus beban yang terpakai. Semakin tinggi daya dan arus beban maka semakin tinggi efisiensi generator dan semakin kecil rugi daya pada generator.
\end{abstract}

Kata kunci : Efisiensi, Pembebanan, Efisiensi Generator, Arus beban

\section{ABSTRACT}

To determine the efficiency of the generator and the power loss in Borang gas power plant, we have to do the calculations manually and using MATLAB software, calculation of the efficiency of the generator and the power loss by using MATLAB software is done by collecting data in the form of unused power generator and the load current. Based on calculations manually and by using MATLAB software-based GUI, the highest efficiency at the power plant during peak load Borang obtained by 99.88\%. While the lowest efficiency for manual calculation results obtained when the load is highest at $99.87 \%$. And calculating results with the manual calculation of power losses are smaller when compared to using MATLAB software, the smallest power losses during peak hours is $0.0112 \mathrm{MW}$ and the largest power losses during peak hours is $0.0136 \mathrm{MW}$. Efficiency and power loss is strongly influenced by the power and load current are used. The higher the power and the load current, the higher efficiency and the smaller generator power losses in the generator.

Keywords: Efficiency, Load, Power Loss, Power, load current

\section{PENDAHULUAN}

Pembangunan di bidang ketenagalistrikan menjadi prioritas utama pemerintah karena tenaga listrik merupakan kebutuhan primer yang harus dipenuhi. Saat ini, tenaga listrik menjadi tenaga penggerak sektor industri di Indonesia membutuhkan listrik baik sebagai energi utama maupun energi pelengkap. Dengan bergeraknya sektor industri ini, otomatis sektor ekonomi juga ikut bergerak. oleh sebab itu tenaga listrik menjadi kebutuhan vital untuk meningkatkan pembangunan ekonomi dan 
kualitas kehidupan bangsa. Pemerintah selaku pembuat kebijakan ekonomi selalu memberikan prioritas utama pada pembangunan nasional sebagai upaya pemenuhan kebutuhan penyediaan tenaga listrik bagi masyarakat. Dalam usahanya dalam memenuhi tingginya kebutuhan akan tenaga listrik ini, perusahaan tentunya akan menemui berbagai kendala dan kesulitan.

Salah satu peralatan yang menunjang energi listrik pada PLTG adalah generator. Kehandalan generator dalam pengoperasian PLTG sangat berpengaruh pada energi listrik yang dihasilkan. Oleh karena itu, perlu dilakukan analisa pengaruh pembebanan terhadap efisiensi generator di PLTG Borang menggunakan Matlab.

\section{TINJAUAN PUSTAKA}

Dalam tulisan tentang Generator Listrik Arus Bolak-Balik, Abdul wahab menerangkan bahwa generator merupakan sebuah alat yang mampu menghasilkan arus listrik. Generator Arus Bolak-balik sering disebut juga sebagai alternator atau generator AC (alternating current) atau juga generator sinkron. Alat ini sering dimanfaatkan di industri untuk mengerakkan beberapa mesin yangmenggunakan arus listrik sebagai sumber penggerak.

Generator sinkron (altenator) merupakan jenis mesin listrik yang berfungsi untuk menghasilkan tegangan bolak-balik dengan cara mengubah energi mekanis menjadi energi listrik. Energi mekanis diperoleh dari putaran rotor yang digerakkan oleh penggerak mula (prime mover), sedangkan energi listrik diperoleh dari proses dari proses induksi elektromagnetik yang terjadi pada kumparan stator dan rotornya. (wahyukr,h;20)

\section{Prinsip Kerja Generator Sinkron}

Prinsip kerja dari generator sinkron dapat dinyatakan sebagai berikut :

- Rotor disuplai dengan arus DC $I_{f}$ yang kemudian menghasilkan fluks magnet ${ }_{f}$.

- Rotor digerakkan oleh turbin dengan kecepatan konstan sebesar $\mathrm{n}_{\mathrm{s}}$.

- Garis gaya magnet bergerak menginduksi kumparan pada stator.

- Frekuensi dari tegangan generator tergantung dari kecepatan putaran rotor yang dapat dinyatakan dengan persamaan:

$$
\begin{aligned}
& \mathrm{f}=\frac{p}{2} \times \frac{n}{60}=\frac{p n}{120} \\
& \text { dimana: } \mathrm{f} \quad=\text { frekuensi }(\mathrm{Hz}) \\
& \mathrm{p} \quad=\text { jumlah kutub } \\
& \mathrm{n} \quad=\text { kecepatan putaran rotor (rpm) }
\end{aligned}
$$

Adapun besar GGL induksi kumparan stator atau GGL induksi armatur per fasa adalah :

$$
\mathrm{E}_{\mathrm{a}} / \mathrm{ph}=4,44 \text {. f. M. . } \mathrm{K}_{\mathrm{d}}
$$

\section{dimana :}

$\mathrm{E}_{\mathrm{a}} \quad=$ Gaya gerak listrik armatur per fasa (volt)

$\mathrm{f} \quad=$ Frekuensi output generator $(\mathrm{Hz})$

$\mathrm{M}=$ Jumlah kumparan per fasa $=\mathrm{Z} / 2$

$\mathrm{Z} \quad=$ Jumlah konduktor seluruh slot per fasa

$\mathrm{k}_{\mathrm{d}} \quad=$ Faktor distribusi. Hal ini diperlukan karena kumparan armatur atau alternator tidak terletak di dalam satu slot melainkan terdistribusi dalam beberapa slot per fasa $=$ Flux magnet per kutub per fasa 


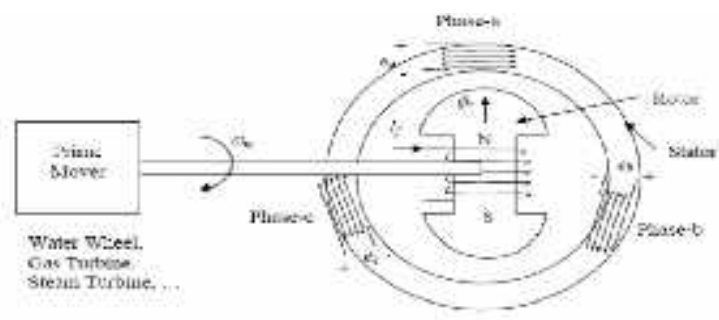

Gambar 2. Prinsip Kerja Generator Sinkron

\section{Efisiensi Generator}

Efisiensi generator adalah perbandingan antara daya output dengan daya input. Seperti halnya dengan mesin- mesin listrik lainnya, maupun transformator, maka efisiensi generator sinkron dapat dituliskan seperti Persamaan :

$$
\begin{aligned}
& \eta=\frac{\text { Pout }}{\text { Ptn }} X 100 \% \text {......................................................... } \\
& \text { (Yon Rijono, } 2004: 244)
\end{aligned}
$$

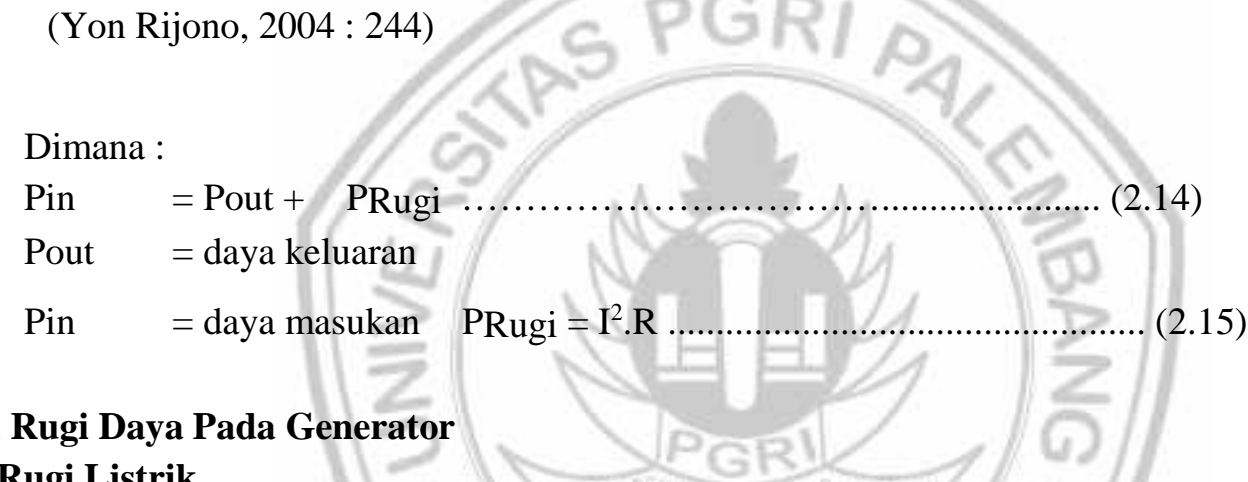

\section{Rugi Rugi Daya
1. Rugi Listrik}

Rugi listrik dikenal juga dengan rugi tembaga yang terdiri dari kumparan armatur, kumparan medan. Rugi - rugi tembaga ditemukan pada semua belitan pada mesin, dihitung berdasarkan pada tahanan dc dari lilitan pada suhu $75^{\circ} \mathrm{C}$ dan tergantung pada tahanan efektif dari lilitan pada fluks dan frekuensi kerjanya. (Kadir Abdul,2010). Rugi kumparan armatur ( $\mathrm{Par}=\mathrm{Ia}^{2}$. Ra $)$ sebesar sekitar 30 sampai $40 \%$ dari rugi total pada beban penuh.

Sedangkan rugi kumparan medan shunt $\left(\mathrm{Psh}=\mathrm{Ish}^{2}\right.$. Rsh) bersama-sama dengan kumparan medan seri $(\mathrm{Psr}=\mathrm{Isr})$ sebesar sekitar 20 sampai 30\% dari rugi beban penuh. Sangat berkaitan dengan rugi $I^{2} R$ adalah rugi - rugi kontak sikat pada cincin slip dan komutator, rugi ini biasanya diabaikan pada mesin induksi dan mesin serempak, dan pada mesin dc jenis industri tegangan jatuh pada sikat dianggap tetap sebesar $2 \mathrm{~V}$ keseluruhannya jika dipergunakan sikat arang dan grafit dengan shunt.

\section{Rugi Besi}

Rugi besi disebut juga rugi magnetik yang terdiri dari histerisis dan rugi arus pusar atau arus eddy yang timbul dari perubahan kerapatan fluks pada besi mesin dengan hanya lilitan peneral utama yang diberi tenaga pada generator sinkron rugi ini dialami oleh besi armatur, meskipun pembentukan pulsa fluks yang berasal dari mulut celah akan menyebabkan rugi pada besi medan juga, terutama pada sepatu kutub atau permukaan besi medan. (muslis, Supari,2008) .

Rugi ini biasanya data diambil untuk suatu kurva rugi - rugi besi sebagai fungsi dari tegangan armatur disekitar tegangan ukuran. Maka rugi besi dalam keadaan terbebani ditentukan sebagai harga pada suatu tegangan yang besarnya sama dengan tegangan ukuran yang merupakan perbedaan dari 
jatuhnya tahanan ohm armatur pada saat terbebani. Rugi histerisis $(\mathrm{Ph})$ dapat dinyatakan dalam bentuk persamaan empiris yang besarnya adalah :

$$
\mathrm{Ph}=\eta \mathrm{h} . \quad \text { Bmax } 1 . \beta . \mathrm{v}(\text { watt })
$$

Dimana :

$\eta \mathrm{h}=$ koefisien steinmetz histerisis. Perhatikan tabel 2.1 tentang nilai $\eta \mathrm{h}$ dari bermacam - macam bahan baja .

$\mathrm{B}=$ kerapatan flux $\left(\mathrm{Wb} / \mathrm{m}^{2}\right)$

$\mathrm{v}=\operatorname{volume}$ inti $\left(\mathrm{m}^{3}\right)$

$\mathrm{f} \quad$ frekuensi $(\mathrm{Hz})$

Tabel 1 Nilai Koefisien Steinmentz Histerisis

\begin{tabular}{|c|c|}
\hline Bahan & $\eta \mathbf{h}(\mathbf{j o u l e} / \mathbf{m 3})$ \\
\hline Sheet steel & 502 \\
\hline Silicon steel & 191 \\
\hline Hard Cast steel & 7040 \\
\hline Cast steel & $750-3000$ \\
\hline Cast iron & $2700-4000$ \\
\hline
\end{tabular}

Dari persamaan, besar koefisien steinmentz histerisis, kerapatan flux dan volume inti adalah konstan sehingga nilai rugi histerisis adalah merupakan fungsi dari frekuensi atau ditulis ;

$\mathrm{Ph}=\mathrm{F}(\mathrm{f})$

Jadi makin besar frekuensi sinyal tegangan output makin besar rugi histerisis yang diperoleh.

Adapun rugi arus pusar atau rugi arus eddy tergantung kuadrat dari kerapatan fluks, frekuensi dan ketebalan dari lapisan pada kedaan mesin normal besarnya adalah:

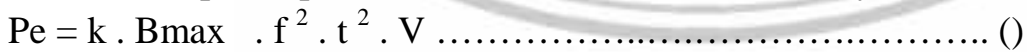

Dimana $: \mathrm{k}=$ konstanta arus pusar yang tergantung pada ketebalan laminasi masing-masing lempengan dan volume inti armatur. Oleh karena nilai $\mathrm{k}$ dan $\mathrm{b}$ adalah konstan, maka besar kecilnya rugi arus pusar adalah tergantung pada nilai frekuensi kuadrat atau ditulis :

$$
\mathrm{Pe}=\mathrm{F}(\mathrm{f})^{2}
$$

Besar rugi besi adalah sekitar 20 sampai $30 \%$ dari rugi total pada beban penuh.

\section{Rugi Mekanik}

Rugi mekanik terdiri dari :

a. Rugi gesek yang terjadi pada pergesekan sikat dan sumbu. Rugi ini dapat diukur dengan menentukan masukan pada mesin yang bekerja pada kecepatan yang semestinya tetapi tidak diberi beban dan tidak diteral.

b. Rugi angin (windageloss) atau disebut juga rugi buta (stray loss) akibat adanya celah udara antara bagian rotor dan bagian stator. Besar rugi mekanik sekitar 10 sampai $20 \%$ dari rugi total pada beban penuh. 


\section{METODE PENELITIAN}

Tabel 2. Data Generator Gas Unit LM2000 PLTG Borang

\begin{tabular}{|l|l|}
\hline Protection & IP 54 \\
\hline Type & Frame : 650 L2X PEP-AFT \\
\hline Output & $22.500 \mathrm{kVA}$ \\
\hline Rated Speed & $3000 \mathrm{rpm}$ \\
\hline Frequency & $50 \mathrm{~Hz}$ \\
\hline Voltage & $11.500 \mathrm{~V}$ \\
\hline Excitation Voltage & $226 \mathrm{~V}$ \\
\hline Insulation Class & Armature F Field F \\
\hline Temp. Rise of Armature & $119^{\circ} \mathrm{C}$ \\
\hline Standard & IEC 60034 \\
\hline Serial No. & $1 \mathrm{~A} 5316 \mathrm{RJ} 1$ \\
\hline Cooling & IC3A1 \\
\hline Rating & Cont. \\
\hline Number of Phases & 3 \\
\hline Poles & 2 \\
\hline Power Factor $0-$ & $85 \%$ \\
\hline Armature Amperes & $1130 \mathrm{~A}$ \\
\hline Field Amperes & $364 \mathrm{~A}$ \\
\hline Inlet Air Temp. & $15^{\circ} \mathrm{C}$ \\
\hline Temp. Rise of Field & $115^{\circ} \mathrm{C}$ \\
\hline Z & $10 \%$ \\
\hline R & \\
\hline
\end{tabular}

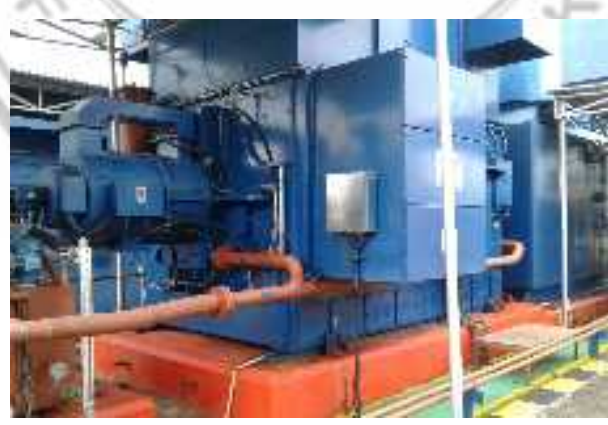

Gambar 3.1 Generator Gas Unit LM2000 PLTG Borang

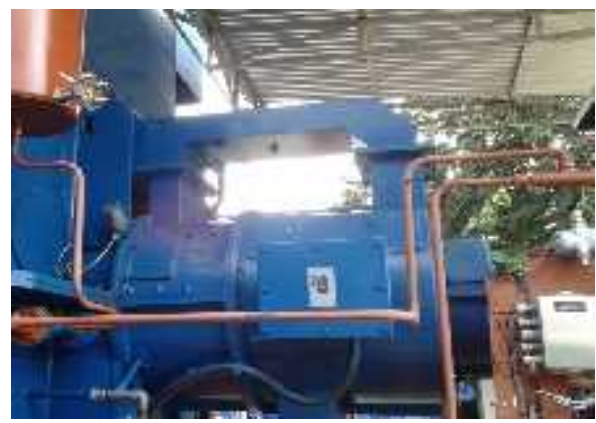


Tabel 3 Data Exciter Generator Gas Unit LM2000 PLTG Borang

\begin{tabular}{|l|l|}
\hline Protection & IP 54 \\
\hline Type & EP - A4 \\
\hline Output & $150 \mathrm{kVA}$ \\
\hline Rated Speed & $3000 \mathrm{rpm}$ \\
\hline Frequency & $100 \mathrm{~Hz}$ \\
\hline Voltage & $240 \mathrm{~V}$ \\
\hline Field Voltage & $81 \mathrm{~V}$ \\
\hline Insulation Class & Armature F Field F \\
\hline Standard & IEC 60034 \\
\hline Cooling & IC3A1 \\
\hline Rating & Cont. \\
\hline Phase & 3 \\
\hline Poles & 4 \\
\hline Power Factor & $90 \%$ \\
\hline Current & $361 \mathrm{~A}$ \\
\hline Coolant Temp. & $15^{\circ} \mathrm{C}$ \\
\hline Date & 2003 \\
\hline & \\
\hline & \\
\hline
\end{tabular}

Gambar 5 Auto Voltage Regulator di PLTG Borang 


\section{Flowchart Perhitungan Efisiensi Generator}

Adapun tahap-tahap dalam perhitungan efisiensi generator dengan software matlab adalah sebagai berikut :

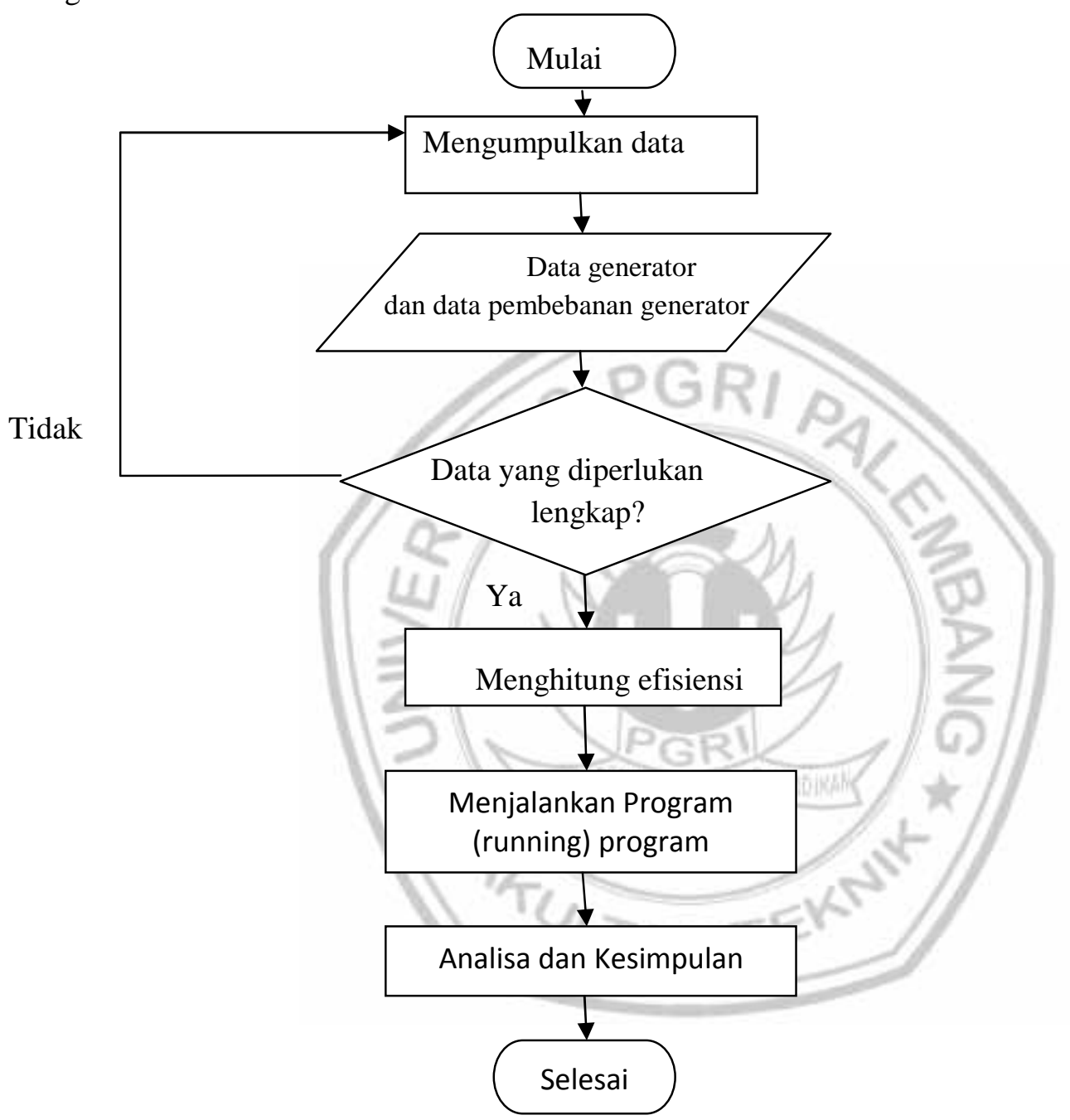

Gambar 6. Flowchart Perhitungan Efisiensi Generator

\section{HASIL DAN ANALISA}

\section{Pembebanan Generator dan Eksitasi Generator}

Berdasarkan Data Pembebanan rata-rata arus dan tegangan pada table dibawah ini, dari tanggal 16-18 Maret 2016 maka dapat terlihat daya keluaran generator dari beban yang terpakai, yang kemudian dapat menghitung rugi daya pada generator dan efisiensi generator.

Tabel 4. Perhitungan Rugi daya dan efisiensi generator pada Tanggal 16 Maret 2016

\begin{tabular}{|l|l|l|}
\hline Jam & Manual & MATLAB \\
\hline
\end{tabular}




\begin{tabular}{|c|c|c|c|c|}
\hline & $\begin{array}{c}\text { Loss } \\
(\mathbf{M W})\end{array}$ & $\begin{array}{c}\text { Efisiensi } \\
(\boldsymbol{\%})\end{array}$ & $\begin{array}{c}\text { Loss } \\
(\mathbf{M W})\end{array}$ & $\begin{array}{c}\text { Efisiensi } \\
(\boldsymbol{\%})\end{array}$ \\
\hline 11.00 & 0,0112 & 99,88 & 0,01145 & 99,88 \\
\hline 12.00 & 0,0113 & 99,88 & 0,01160 & 99,88 \\
\hline 13.00 & 0,0117 & 99,88 & 0,01199 & 99,88 \\
\hline 14.00 & 0,0119 & 99,88 & 0,01219 & 99,88 \\
\hline 15.00 & 0,0116 & 99,88 & 0,01185 & 99,88 \\
\hline 16.00 & 0,0122 & 99,88 & 0,01243 & 99,88 \\
\hline 17.00 & 0,0119 & 99,88 & 0,01219 & 99,88 \\
\hline 18.00 & 0,0114 & 99,88 & 0,01170 & 99,88 \\
\hline 19.00 & 0,0111 & 99,88 & 0,01136 & 99,88 \\
\hline 20.00 & 0,0121 & 99,88 & 0,01233 & 99,88 \\
\hline 21.00 & 0,0114 & 99,88 & 0,0117 & 99,88 \\
\hline 22.00 & 0,0115 & 99,88 & 0,01179 & 99,88 \\
\hline 23.00 & 0,0110 & 99,88 & 0,01122 & 99,88 \\
\hline 00.00 & 0,0117 & 99,88 & 0,01194 & 99,88 \\
\hline 01.00 & 0,0109 & 99,88 & 0,01117 & 99,88 \\
\hline 02.00 & 0,0117 & 99,88 & 0,011194 & 99,88 \\
\hline 03.00 & 0,0118 & 99,88 & 0,01204 & 99,88 \\
\hline 04.00 & 0,0117 & 99,88 & 0,01119 & 99,88 \\
\hline 05.00 & 0,0118 & 99,88 & 0,01204 & 99,88 \\
\hline 06.00 & 0,0116 & 99,88 & 0,01189 & 99,88 \\
\hline 07.00 & 0,0115 & 99,88 & 0,01175 & 99,88 \\
\hline 08.00 & 0,0119 & 99,88 & 0,01213 & 99,88 \\
\hline 09.00 & 0,0115 & 99,88 & 0,01175 & 99,88 \\
\hline 10.00 & 0,0122 & 99,99 & 0,01243 & 99,88 \\
\hline & & & & \\
\hline & & & & \\
\hline
\end{tabular}

Tabel 5. Perhitungan Rugi daya dan efisiensi generator pada Tanggal 17 Maret 2016

\begin{tabular}{|c|c|c|c|c|}
\hline \multirow{2}{*}{ Jam } & \multicolumn{2}{|c|}{ Manual } & \multicolumn{2}{c|}{ MATLAB } \\
\cline { 2 - 5 } & $\begin{array}{c}\text { Loss } \\
(\mathbf{M W})\end{array}$ & $\begin{array}{c}\text { Efisiensi } \\
(\boldsymbol{\%})\end{array}$ & $\begin{array}{c}\text { Loss } \\
(\mathbf{M W})\end{array}$ & $\begin{array}{c}\text { Efisiensi } \\
(\boldsymbol{\%})\end{array}$ \\
\hline 11.00 & 0,0116 & 99,88 & 0,01185 & 99,87 \\
\hline 12.00 & 0,0118 & 99,88 & 0,01209 & 99,87 \\
\hline 13.00 & 0,0122 & 99,87 & 0,01249 & 99,87 \\
\hline 14.00 & 0,0116 & 99,88 & 0,01185 & 99,87 \\
\hline 15.00 & 0,0126 & 99,87 & 0,01294 & 99,87 \\
\hline 16.00 & 0,0125 & 99,87 & 0,01278 & 99,87 \\
\hline 17.00 & 0,0126 & 99,87 & 0,01288 & 99,87 \\
\hline 18.00 & 0,0121 & 99,87 & 0,01233 & 99,87 \\
\hline 19.00 & 0,0133 & 99,87 & 0,01360 & 99,87 \\
\hline 20.00 & 0,0136 & 99,87 & 0,01387 & 99,87 \\
\hline 21.00 & 0,0124 & 99,87 & 0,01268 & 99,87 \\
\hline 22.00 & 0,0119 & 99,88 & 0,01219 & 99,87 \\
\hline 23.00 & 0,0119 & 99,88 & 0,01219 & 99,87 \\
\hline 00.00 & 0,0119 & 99,88 & 0,01213 & 99,88 \\
\hline
\end{tabular}




\begin{tabular}{|l|l|l|l|l|}
\hline 01.00 & 0,0112 & 99,88 & 0,01145 & 99,88 \\
\hline 02.00 & 0,0114 & 98,87 & 0,01170 & 99,88 \\
\hline 03.00 & 0,0111 & 99,88 & 0,01136 & 99,88 \\
\hline 04.00 & 0,0117 & 99,88 & 0,01199 & 99,88 \\
\hline 05.00 & 0,0117 & 99,88 & 0,01194 & 99,88 \\
\hline 06.00 & 0,0113 & 99,88 & 0,01155 & 99,88 \\
\hline 07.00 & 0,0116 & 99,88 & 0,01189 & 99,88 \\
\hline 08.00 & 0,0121 & 99,88 & 0,01239 & 99,88 \\
\hline 09.00 & 0,0116 & 99,88 & 0,01185 & 99,88 \\
\hline 10.00 & 0,0117 & 99,88 & 0,01194 & 99,88 \\
\hline
\end{tabular}

Tabel 6. Perhitungan Rugi daya dan efisiensi generator pada Tanggal 18 Maret 2016

\begin{tabular}{|c|c|c|c|c|}
\hline \multirow{2}{*}{ Jam } & \multicolumn{2}{|c|}{ Manual } & \multicolumn{2}{c|}{ MATLAB } \\
\cline { 2 - 5 } & $\begin{array}{c}\text { Loss } \\
(\mathbf{M W})\end{array}$ & $\begin{array}{c}\text { Efisiensi } \\
(\boldsymbol{\%})\end{array}$ & $\begin{array}{c}\text { Loss } \\
(\mathbf{M W})\end{array}$ & $\begin{array}{c}\text { Efisiensi } \\
(\boldsymbol{\%})\end{array}$ \\
\hline 11.00 & 0,0116 & 99,87 & 0,01278 & 99,87 \\
\hline 12.00 & 0,0118 & 99,88 & 0,01209 & 99,88 \\
\hline 13.00 & 0,0122 & 99,88 & 0,01223 & 99,88 \\
\hline 14.00 & 0,0116 & 99,87 & 0,01223 & 99,88 \\
\hline 15.00 & 0,0126 & 99,88 & 0,01189 & 99,88 \\
\hline 16.00 & 0,0125 & 99,87 & 0,01239 & 99,88 \\
\hline 17.00 & 0,0126 & 99,88 & 0,0117 & 99,88 \\
\hline 18.00 & 0,0121 & 99,87 & 0,01254 & 99,88 \\
\hline 19.00 & 0,0133 & 99,87 & 0,01258 & 99,88 \\
\hline 20.00 & 0,0136 & 99,88 & 0,01204 & 99,88 \\
\hline 21.00 & 0,0124 & 99,88 & 0,01126 & 99,88 \\
\hline 22.00 & 0,0119 & 99,88 & 0,01233 & 99,88 \\
\hline 23.00 & 0,0119 & 99,88 & 0,01155 & 99,88 \\
\hline 00.00 & 0,0119 & 99,88 & 0,01199 & 99,88 \\
\hline 01.00 & 0,0112 & 99,88 & 0,01151 & 99,88 \\
\hline 02.00 & 0,0114 & 98,88 & 0,01223 & 99,88 \\
\hline 03.00 & 0,0111 & 99,88 & 0,01199 & 99,88 \\
\hline 04.00 & 0,0117 & 99,88 & 0,01199 & 99,88 \\
\hline 05.00 & 0,0117 & 99,88 & 0,01243 & 99,88 \\
\hline 06.00 & 0,0113 & 99,88 & 0,01141 & 99,88 \\
\hline 07.00 & 0,0116 & 99,88 & 0,01219 & 99,88 \\
\hline 08.00 & 0,0121 & 99,88 & 0,01194 & 99,88 \\
\hline 09.00 & 0,0116 & 99,88 & 0,01223 & 99,88 \\
\hline 10.00 & 0,0117 & 99,88 & 0,01194 & 99,88 \\
\hline & & & & \\
\hline
\end{tabular}




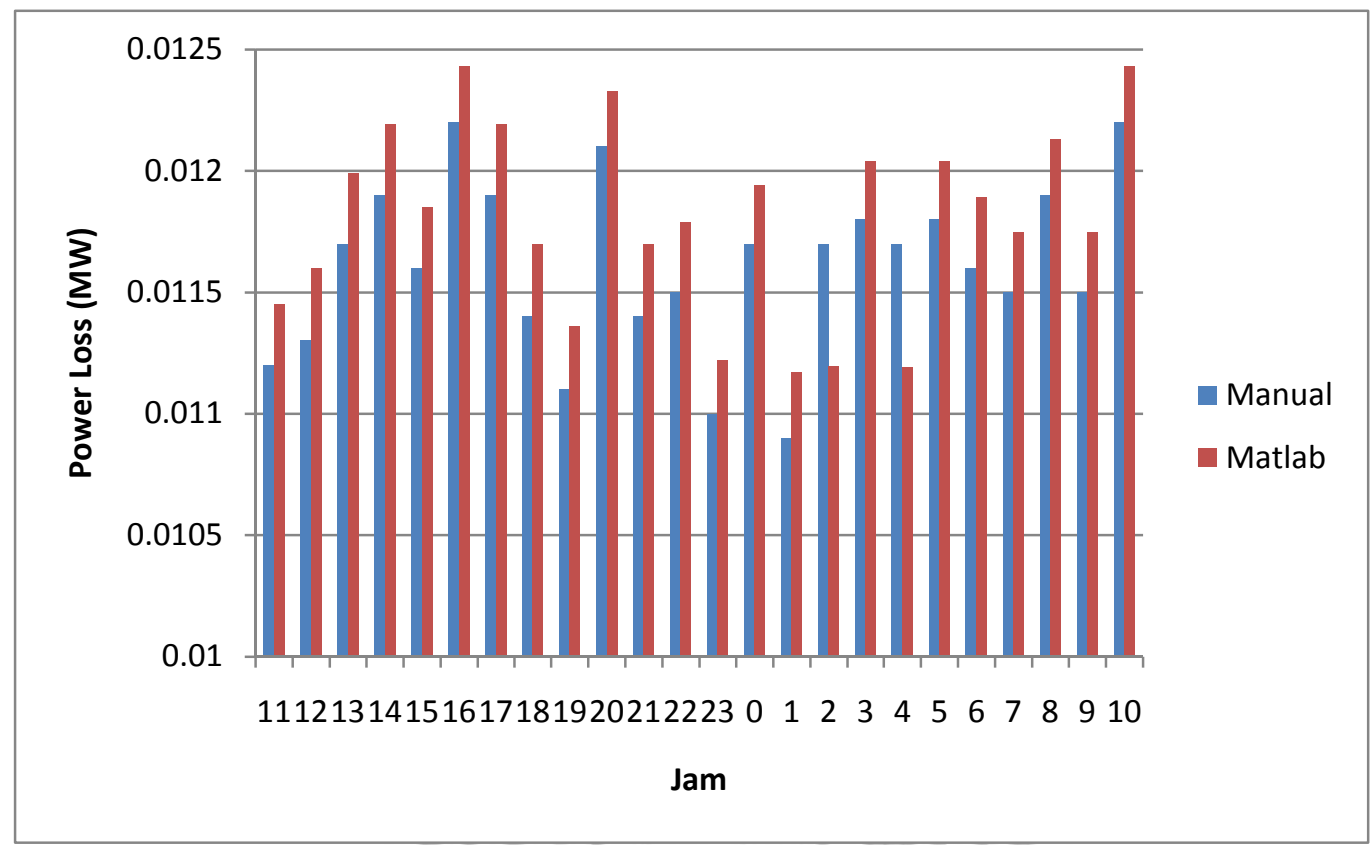

Gambar 6. Grafik Perbandingan Perhitungan Power Loss secara Manual dan Perhitungan Menggunakan Matlab pada 16 Maret 2016

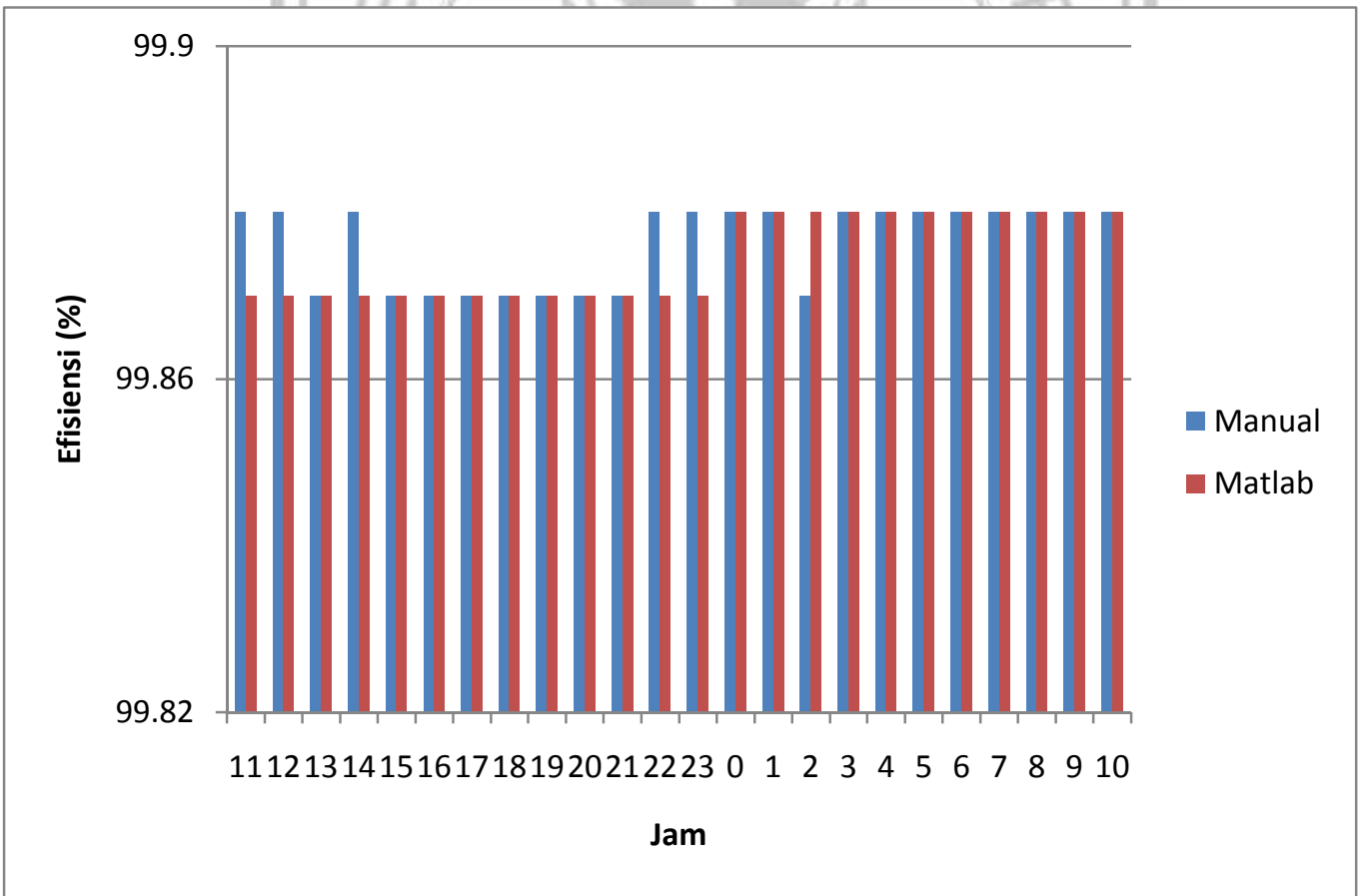

Gambar 7. Grafik Perbandingan Perhitungan Efisiensi secara Manual dan Perhitungan Menggunakan Matlab pada 17 Maret 2016 


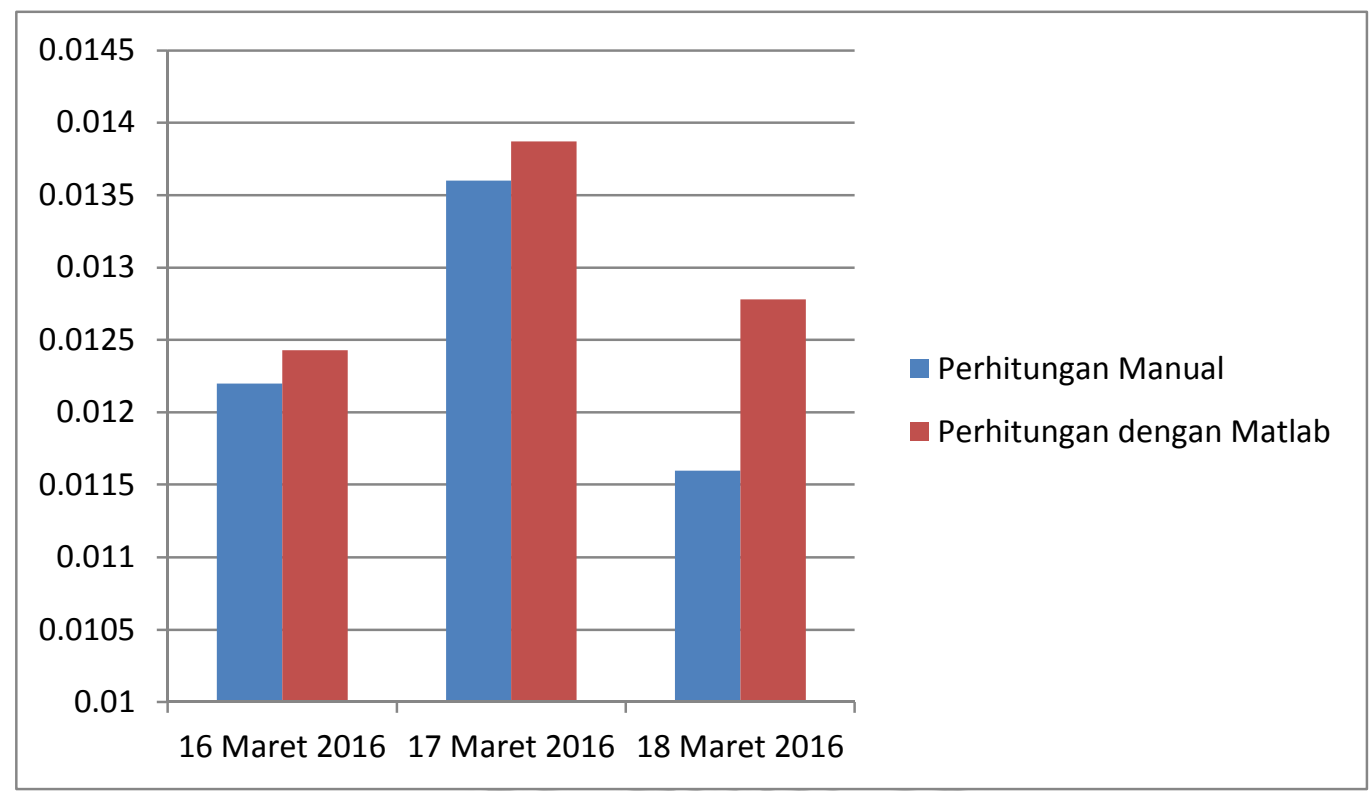

Gambar 8. Grafik Perbandingan Perhitungan Power Loss secara Manual dan Perhitungan Menggunakan Matlab pada kondisi beban puncak periode 16-18 Maret 2016

\section{Analisa}

Berdasarkan data pembebanan generator unit LM2000 PLTG Borang, dapat dilihat dari tabel 4.1 sampai dengan 4.3 ini memiliki karakteristik nilai perbandingan yang hampir sama antara besar nilai efisiensi.

Efisiensi yang didapat dari hasil perhitungan berdasarkan perbandingan daya keluaran terhadap daya masukkan dari tanggal 16 Maret 2016 sampai 18 Maret 2016 disini terlihat bahwa ratarata efisiensi perhari pada generator tersebut berkisar antara $99.87 \%$ sampai $99.88 \%$. Jika semakin besar daya keluarannya atau daya yang terpakai maka tingkat efisiensi generator akan semakin tinggi karena efisiensi generator sangat dipengaruhi oleh beban beban yang terpakai yang sesuai dengan kemampuan dan kapasitas generator.

Nilai hasil perhitungan rugi daya dan efisiensi dengan menggunakan matlab rata-rata lebih besar dibandingkan dengan perhitungan secara manual, hal ini dikarenakan jika menghitung menggunakan matlab maka hasil akan lebih akurat. Contohnya, jika menghitung secara manual maka kita mungkin akan membulatkan angka hanya menjadi 2 desimal, sedangkan di program matlab tetap menggunakan angka asli tanpa pembulatan. Bisa dilihat pada gambar 4.13 dan 4.14.

Nilai efisiensi bervariasi tergantung dari nilai arus beban dan daya beban yang terpakai. Nilai arus beban dan daya beban juga mempengaruhi rugi daya, semakin kecil nilai dari rugi daya maka semakin meningkat nilai efisiensi.

\section{KESIMPULAN}

1. Nilai efisiensi generator ini sangat dipengaruhi oleh beban yang terpakai, pada PLTG Borang besarnya beban yang terpakai adalah fluktuatif, dan nilai beban puncak berkisar antara 10,2 10,6 MW pada range waktu 16.00-20.00 WIB.

2. Nilai efisisensi generator juga dipengaruhi oleh rugi daya beban yang terpakai, pada PLTG Borang besarnya rugi daya berkisar 0,0112 MW- 0,0136 MW. Perhitungan rugi daya dengan menggunakan Software MATLAB menghasilkan nilai yang lebih besar dibanding hasil perhitungan manual. 
3. Pada periode 16 - 18 Maret 2016, nilai rata rata efisiensi generator di PLTG Borang adalah 99,88\%. Dimana perbandingan perhitungan manual dan menggunakan Software MATLAB hanya berbeda $0,01 \%$.

\section{DAFTAR PUSTAKA}

1. Abdul Wahab, Generator Listrik Bolak-Balik, https://wahabxxxxx.files.wordpress.com/2011/04/generator-ac.pdf

2. Berahim, Hamzah ; Pengantar Teknik Listrik, Andi Offset, Yogyakarta, 1994

3. Kadir, Abdul; Pembangkit Tenaga Listrik, UI Press, Jakarta, Edisi Revisi, 2010

4. Muslis, Supari, Teknik Pembangkit Tenaga Listrik, Jakarta : Departemen Pendidikan Nasional. 2008

5. Wahyu, Teori Generator Sinkron, hal 20 http://wahyukr.staff.gunadarma.ac.id/Downloads/.../5+TEORI+GENERATOR+SINKRON.p...

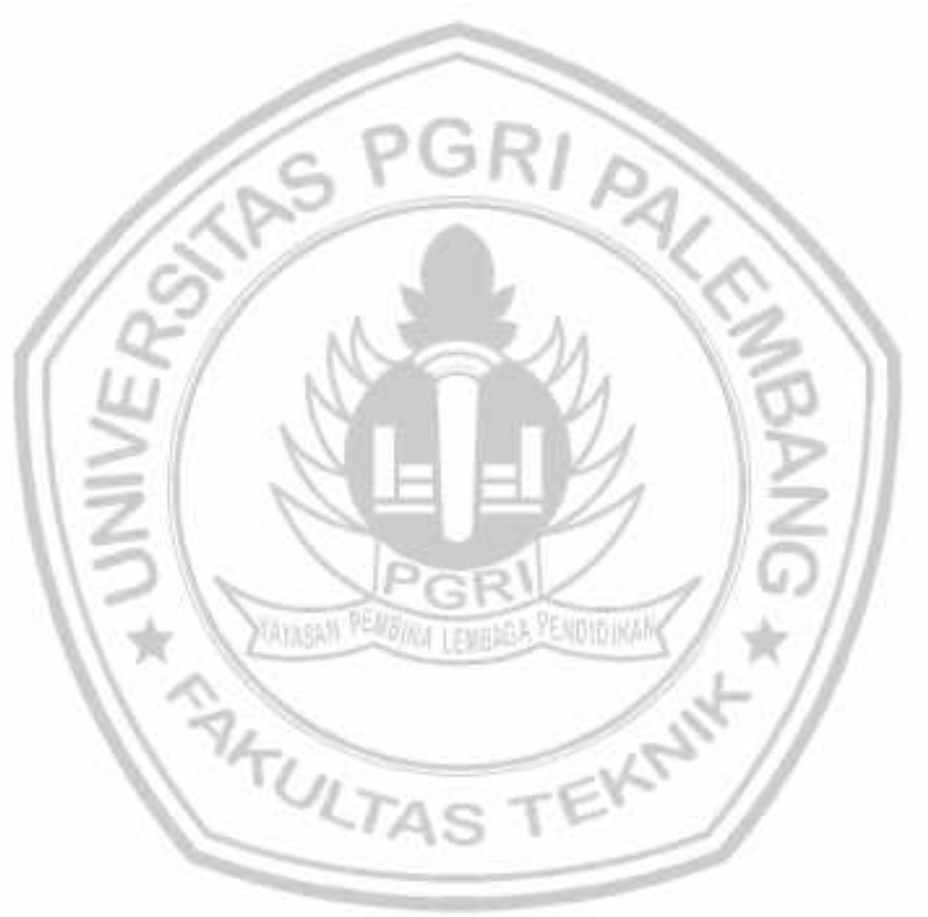

